História (São Paulo)

http://dx.doi.org/10.1590/1980-436920150001000045

Tiles of Mercy: an image document of the history of Luso-Brazilian religious culture

\title{
Os azulejos da Misericórdia: a imagem documento na história da cultura religiosa luso-brasileira
}

\author{
Maria Eurydice de Barros RIBEIRO \\ UnB - University of Brasilia \\ Contact: maeurydice@yahoo.com.br
}

\begin{abstract}
Portuguese tiles in Portugal and Brazil are often considered as objects belonging to the History of Art. The purpose of this study is to address the tiles not as objets d'arte but as documents of the history of Luso-Brazilian culture. The concept of an image document will be developed through the analysis of one of the most important rites of the history of Western religious culture: the procession. The study will focus in particular on the Procession of the Bones, which is represented in the panels of the tiles (c. XVIII) of the Church of Mercy in Salvador. The Procession of the Bones, instituted by King Manuel in 1498, was intended for the removal of bones of those brought to justice, and to provide them with a burial. For the mission, the king appointed the Order of Mercy. This Royal act was extended to Brazil when the first House of Mercy was founded in the city of Salvador in 1549. The panel, dating from the eighteenth century, and representing the ceremony, divides the Church of Mercy with two other representations: the Procession of the Dead Lord, introduced in Brazil (also by the Portuguese), and the Procession of the Torches, introduced by the Spanish. Between the date of the first Procession of the Bones and the laying of the panel of tiles, there is a time frame that evaluates the heterogeneity of art periods, where differentiated rhythms do not necessarily coincide with the periods of history.
\end{abstract}

Keywords: Religious art; Tiling; Luso-Brazilian culture.

Resumo: Os azulejos portugueses em Portugal e no Brasil são considerados quase sempre como objetos da História da Arte. A proposta deste estudo consiste em abordar os azulejos não como objetos de arte, mas como documentos da história da cultura luso-brasileira. O conceito de imagem documento será desenvolvido por meio da análise de um dos ritos mais importantes da história da cultura religiosa ocidental: a procissão. A atenção do estudo recairá, em especial, sobre a Procissão dos Ossos, que se encontra representada nos painéis de azulejos (séc. XVIII) da Igreja da Misericórdia em Salvador. A Procissão dos Ossos, instituída por D. Manoel em 1498, tinha como objetivo a retirada dos ossos dos justiçados, dando-lhes sepultura. Para a missão, o rei designou a Ordem da Misericórdia. O ato régio se estendeu ao Brasil, quando a primeira Casa da Misericórdia foi fundada na cidade do Salvador, em 1549. O painel, datado do século XVIII, representando a cerimônia, divide o espaço da igreja da Misericórdia com outras duas representações: a procissão do Senhor Morto, introduzida no Brasil (também pelos portugueses), e a Procissão do Fogaréu, introduzida pelos espanhóis. Entre a data da realização da primeira Procissão dos Ossos e o assentamento do painel de azulejos existe um espaço de tempo que permite avaliar a heterogeneidade dos tempos da arte, onde os ritmos diferenciados não coincidem, necessariamente, com os tempos da história.

Palavras-chave: Arte religiosa; azulejaria; cultura luso-brasileira. 
In the church of Our Lady of Mercy in Salvador (Bahia), there are four panels of tiles representing three major processions from Iberian Christianity: The Procession of the Dead Lord, introduced in Brazil by the Portuguese; the Procession of the Torches, which was introduced by the Spanish; and the Procession of the Bones, established by King Manoel in 1498. The latter had, among its objectives, the annual removal of the bones of those brought to justice, in order to give them a Christian burial. For the mission, the king appointed the Order of Mercy, founded in Lisbon by Queen Leonor of Lancaster (1458-1525). This royal act was extended to Brazil when the first Holy House was founded in the city of Salvador in 1548. The following year, the Brotherhood was founded in the first hospital ward, a chapel, which was a victim of the bombings resulting from the Dutch in the early seventeenth century (1624/1625). The present church was built in 1653 and spent the early eighteenth century (1722) undergoing major renovations that have made it a building of great beauty. Part of this beauty is due to the installation of tiles on the walls and in the aisles. The creation of Antonio de Abreu, these tiles came directly from Lisbon. The focus of this study is the panel which represents the procession of the bones. Recently, the panels underwent a restoration process, whose technical accuracy revived the freshness and charm of the original sections.

According to the archives of the Holy House, "the exercise of charitable functions of the Brotherhood shall begin with the foundation of the chapel and the hospital" (RIBEIRO, 1993, p. 8). The Brotherhood referred to it then as the Commitment to the Mercy of Lisbon, which determined the 14 works of mercy (seven spiritual works and seven corporal) that would befit the Brothers. Among the latter was to bury the dead. The bi-chrome panel in blue and white depicts three large coffins of bones being transported by the Brothers in procession.

Throughout history, social practices of various nature have sought to be represented figuratively. The work of Mercy was no exception. The need for the figurative representation of the bones of the procession finds clarification in the socio-cultural conditions which include the order of the panels, in particular by those who commissioned them and for what they were commissioned. It is necessary to understand the composition of social groups that dwelt in the city. The eighteenthcentury slave Bahian society was then marked by great piety and deep social inequality. The city of Salvador consists of narrow streets and a hot and humid climate, favoring the proliferation of various diseases and even epidemics (RIBEIRO, 1993, p. 2). This scenario stimulated charitable social actions, as occurred in thirteenth century Europe, whose growing urban poverty motivated the spiritual development of the apostolic foundation. The mendicant orders and tertiary orders were established overseas, driven by mutual commitments that united the Christian Church. The Tertiary Brotherhoods sought to carry out good deeds to alleviate the suffering of the poor. 
The panel of tiles representing the Procession of the Bones was custom made by the Brotherhood of Mercy, the Third most prestigious Order in the Brazilian colony. In accordance with the Commitment of the Order of Lisbon, the brothers, "in order to serve God and his poor with due perfection, shall have seven conditions". The first condition stipulated was to be, "clean of blood, without any trace of the Moorish or Jewish race, not only in his person, but also his wife". Approximately a century prior to the installation of the tiles at the beginning of the 17th century, a new commitment was produced. In the following century, when the tiles were already installed (1775), the Marquis of Lavradio, then Ombudsman of the Holy House, ordered that it should, "moderate, reconcile and scribe in a way that most were unable to read the third paragraph of Chapter 1 of the Commitment which was the number and qualities that the Brothers of Mercy must have" (RIBEIRO, 1993, p. 10). It is likely, on the one hand, that the paragraph referring to the "cleanliness of blood" would be difficult to administer in the colony which had received a substantial number of Marranos. On the other hand, times were different and it was insisted that the brothers were men of "good conscience and fame, God-fearing, modest, charitable and humble" (RIBEIRO, 1993, p. 10). The Order of Mercy, faithful to principles of apostolic origin, sought to implement its actions based directly on the Gospel. The image of the Virgin Mary with her robe open welcoming everyone was inspired by the brothers who attended processions, masses and burial ceremonies.

As we saw above, the installation of the Order of Mercy in Bahia resulted from an act of the king himself, at that time, King Manoel. The Philippine Ordinances, which governed Brazil from 1603 (when they entered effectively into force) emphasize the socio-religious role of the Order. Regarding what is of interest to this study - the Procession of the Bones - Book V, which deals with Rights, Proceedings and the Execution of Sentences, in Title CXXXVII, Executions of Corporal Punishment, referring to the "death in effect, according to the sentence shall be the content", which is complemented by, "And if instead there is Confraternity of Mercy, let him be notified, to go with him, and comfort him". In fact, from the time of the sentence to the execution the Brotherhood was present, obeying the ordinances which insisted that all efforts were to be made in order that (those punished) they would die as good Christians. "The execution should be carried out as specified giving him time to confess and commune" (TÍTULO 137). As a last word, the Church found royal power and tertiary orders the necessary support for the execution of sacraments. It was as if Mercy consoled the condemned, that is, convinced him to accept death with resignation. At the time, although it was not known when one would die, being prepared for death was an essential part of the concerns of all Christians. In the case of convicts who knew that they were going to die, this preparation took on a different connotation, that of time: three days, as stipulated by the Philippine Ordinances, stating that the third day could not be a Sunday or a holy day. During this period the Brother of Mercy should comfort the condemned man and the chaplain was obliged 
to lead him to confess and go with them to the "place appointed for such Justice, striving on with the words with which good Christians die and receive death with patience" (TÍTULO 137). Within this ritual, where the moment of death was highly valued, both the Brother of Mercy and the confessor were invested with great responsibility. The confession manuals used by the parish priest were testament to the various formulas that could be employed at the time.

It is reported that in Lisbon those sentenced to death went to the gallows in the Fields of Santa Barbara, and the Mercy went and collected them once a year. In the colony, corpses could remain suspended in a place of execution. In the cases of those condemned to death for counterfeiting, the corpse should even be burned. In 1696, the metropolitan government reached an agreement with the Mercy for the burying of abandoned bodies upon the payment of 400 sovereigns. These were bodies that were not claimed by anyone and among them, of course, were the bodies of the condemned. According to João José Reis (REIS, 1991, p. 172), until the first two decades of the 18th century, the cemetery of the Field of Gunpowder was not yet administered by the Holy House, but by the Town Council. The bodies that weren't claimed were buried in the Field of Gunpowder: African slaves dead at the time of the landing of slave ships, those condemned to death, as well as others forgotten by society; so ignored that it was left to public cleaning workers to take care of them. It's worth remembering that at the time abandoned bodies could remain for days until they were buried in almost complete indifference. The evidence indicates that the graveyard that received them was not holy land, and consequently not for the purpose of religious rituals. Buried in mass and shallow graves, they were "at the mercy of hungry animals" (REIS, 1991, p. 172). The onus was on the Holy House to collect the spoils of the convicted on an annual basis, at which time the Brotherhood was preparing the bones for the procession. The death ritual of a condemned person therefore had many acts, whose epilogue would come a year after with the procession along the streets in coffins borne by the brothers. It is with good reason that, referring to an execution as a "spectacle", "lesson", in short a "triumphant death", Michel Vovelle concludes that the baroque death is intensely experienced (VOVELLE, 1974, p. 85). It is precisely these aspects - the spectacle, lesson and triumph - of death that the panel of Mercy exposes, externalizing its own experiences of the participants (alive and dead) in the procession. 


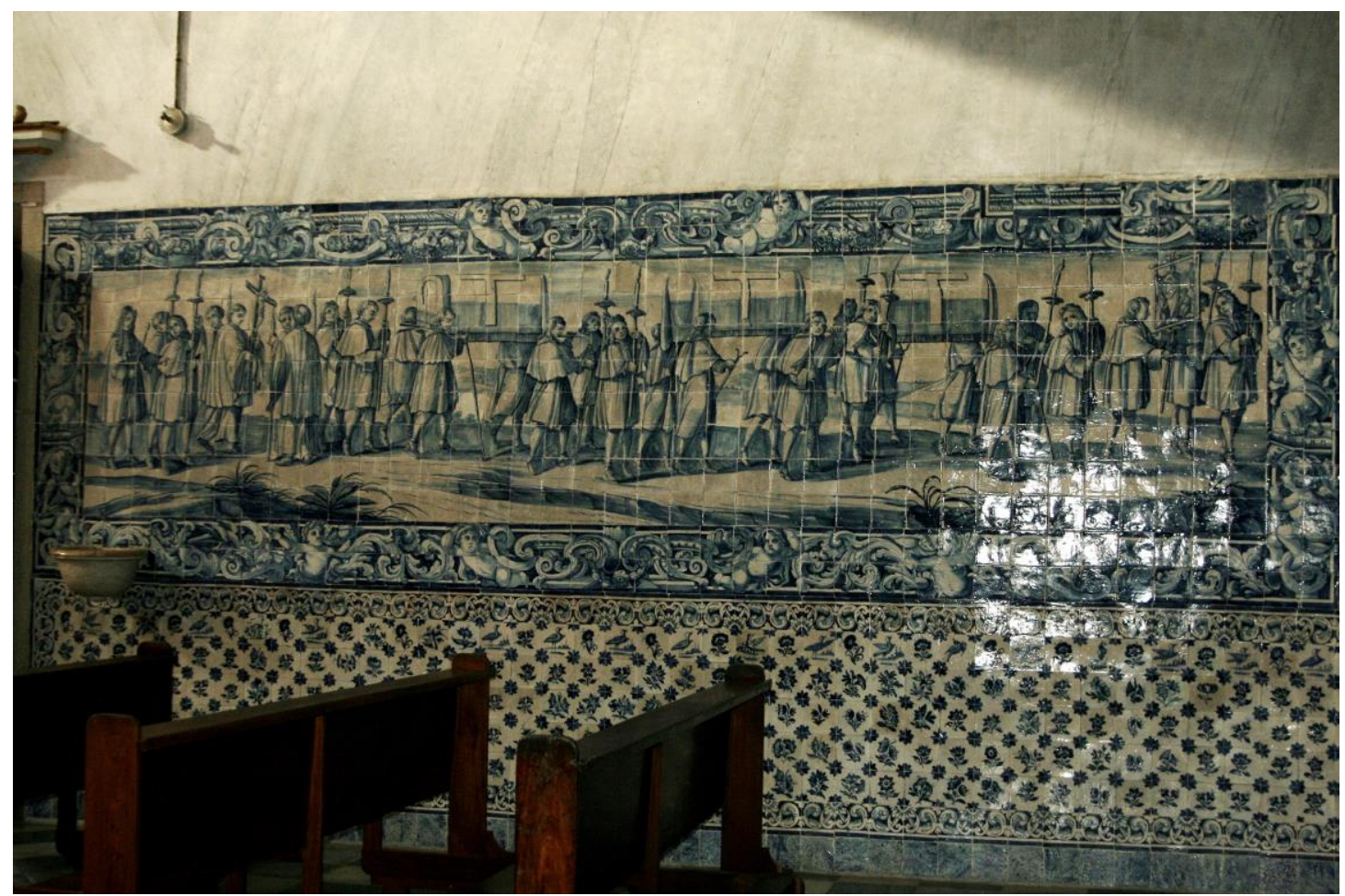

Fig. 1 - Procession of the Bones.

Source: Courtesy of the Holy House of Mercy, Bahia.

It is known that the ceremonies around extraordinary events dating back to Ancient times and through the Middle Ages are one of the many appropriations that the Medieval times made of Roman civilization. Such ceremonies in the ancient world were moved both by the celebration of a victory that came in Rome in a triumphal parade, waving the standard of the great eagle, the greatest symbol of Roman power, and/or, simply, to extol the figure of the emperor. During the Middle Ages, processions and parades "discarded" pagan content, replacing it with Christian sacredness, albeit strictly religious, or in honor of the king, on the occasion of some special event. From the 17th century, in the France of Louis XIV, processions and parades led the celebration of the monarchy in its heyday conquered by the Sun King. The Leviathan State exhibited its force through ceremonies in which the Roman tradition was invoked as the figure of the divine monarch, assuming Christian content. The vaunted splendor of the court of Versailles conquered the other European courts, penetrating Portugal and spreading, of course, to the colonies. The celebrations of the 17th and 18th centuries, baroque celebrations in particular, took on dramatic and ornamental aspects of excess. In Lisbon and in other cities and towns of the kingdom, the ceremonies were staged with great pomp and rigor as the occasion demanded. Transplanted to the American colony, it was not only to imitate the metropolis, which was customary at that time, but the transfer of a long-term historical tradition. The ceremonies were extraordinary events and, therefore, although some have been the result of the landing in Brazil of artists and artisans; others imposed themselves 
on the main Brazilian villages by royal act. This was the case, as mentioned, of the Procession of the Bones.

The panel with the representation of the procession is located on the right-hand side of the entrance to the aisle. On the left side, the Procession of the Torch is the first panel. The proximity to the pulpit and the altar indicates the importance attributed to the procession led by the Brothers and represented in the Church erected by the Order and consecrated to Our Lady of Mercy.

Until the 17th century the confraternities had been satisfied with simple chapels. Beginning in the following century, they began to erect the churches themselves. The constructions over time were becoming increasingly ambitious, due in part to the rivalry that had developed between the Tertiary Brotherhoods. Such competition is revealed in every detail of the religious building, both on the external facade as well as the interior. At the main altar, the richness of the gilded flame even today calls the attention of those visiting these temples. According to Germin Bazin, in a work that has become a reference on the baroque, "the social situation in Brazil, as well as in other parts of Latin America, was particularly favorable to the development of religious art. The civil society, at least during the first two centuries, was a reproduction of what it was in Europe in the early times of the Middle Ages" (BAZIN,1983, p. 25).

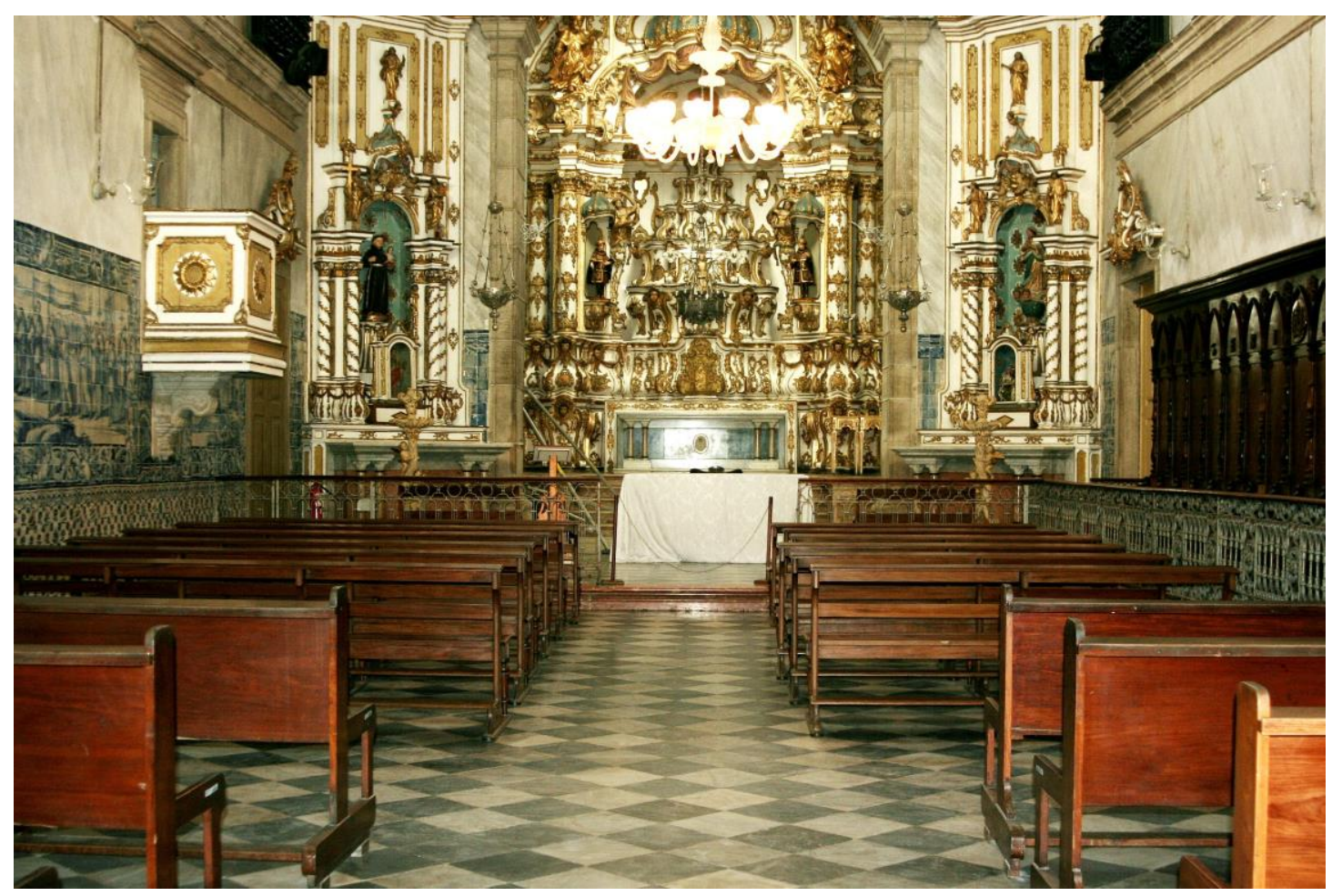

Fig. 2 - Main Altar. The right panel of tiles represents the Procession of the Bones. Source: Courtesy of the Holy House of Mercy, Bahia.

The rectangular panels in blue and white which were exported to Brazil correspond to a new era of Portuguese tiles. From the end of the 17th century, tiles had to be characterized by blue paint, 
"the color associated with the prestigious porcelain of China - that the Portuguese were the first to bring to Europe in large quantities - and was adopted due to the influence of Dutch tiles" (HENRIQUES, 2005, p. 96). At the same time Portuguese churches and palaces underwent important decorative renovations; it was from then on, as notes Paulo Henriques, that "the tile would be avidly sought by a society with new needs of representation by imposing its presence in monumental compositions" (HENRIQUES, 2005, p. 96). It can be concluded that with the tiles that comprised the panels, the Order of Mercy in Bahia also mattered, and for the metropolis, "the need of representation".

The panel which represents the procession of the bones is framed by straight bars with clearly baroque motifs such as the coils of acanthus and mythological figures placed at the center of the top section. At the bottom, the number of figures grows from two to four interspersed harmoniously by coils of acanthus. Below the panel, another panel extends, repeating the same frame constituted by the coils of acanthus. The tiles that join the lower panel with the "separate figure", clearly inspired by the Dutch, are so called because each tile contains a standalone image. The motifs are repeated by small flowers and birds. Usually this type of tile was used "for secondary spaces such as corridors, kitchens and vestries, replacing the standard tile that was little produced in the period" (HENRIQUES, 2005, p. 111). It's use of the aisle of the church, as we can see, complements the tiles at the bottom of the panel and at the same time highlights the aesthetic value of great composition that represents the procession. This type of tile emerged in the last quarter of the 17th century and was widely used in the first half of the 18th century. For some, these tiles were the work of young apprentices (HENRIQUES, 2005, p. 111).

It should be pointed out that since the end of the 17th century, in Portugal, the Portuguese tile was benefited by the work of painters who once again took to signing their works. Art historians in Portugal refer to this period as the, "Cycle of Masters". At that time the painting of artists was designed with a view to covering walls, vaults and domes. The frames had, in general, defined iconographic programs. From the 18th century, the manufacture of tiles increased in order to, among other reasons, meet construction needs in Brazil. It started a new period in the history of Portuguese tiles, which was called the, "Great Production".

Taking as a reference the aisle into the church, it was the beginning of the procession formed by the first group of Brothers of Mercy in sets of five. The first two brandished poles with lighted candles, preceding the brother carrying the standard bearer of the Order, likely to have been a representation of Our Lady of Mercy. Both the poles and the standard are, at the same time, symbols and insignia of the right of Holy House in its public functions, differentiating its members from other tertiary orders. The insignia from ancient times played an important role both in times of war, by differentiating the armies, as well as in times of peace, when indistinguishable from the 
different groups according to the political and/or religious role being exercised (PASTOUREAU, s/d, p. 40-44). They are, therefore, signs of value and hierarchy which gain immense importance in societies characterized by strong social differences and the low or non-existent mobility of groups.

The importance of these signs of power was so great that in 1760 the Brotherhood of the Holy House of Mercy denounced the Crown for having had their ensigns usurped by other two brotherhoods: the Our Lady of Martyrs (formed by blacks or creoles) and the Lord of the Cross (consisting of browns and blacks). The petition made by the Brothers, and the tone of indignation for impinging on the insignia is enlightening. The arguments are based on, among other things, the fact that those to whom it is, by nature, slavery, sought to imitate the greats. Basing it on a royal concession that had its rights protected by papal bulls, the Brotherhood was exposing to the naked eye the paradox of the society in which they lived; it was up to the greats to express their compassion to the lowly according to the teachings of Christ himself but the "humble" ones trying to be "greats" by publicly copying their actions did not fit in (MENDES, 2001, p. 109). In other words, each one should remain in their place.

After the first group, three coffins containing the bones of the wrongdoers covered by fringed blankets belonging to the funeral ceremonies with a Latin cross at the center, were carried by four Brothers respectively. As we know, the Latin cross, crux immissa, is the cross of passion. It reappears in a more explicit manner with the image of Christ crucified at the end of the procession. The message could not be clearer: invoking thus the forgiveness of sins and the Resurrection. All Brothers are dressed in the same capes and buckled shoes; it is not possible to identify whether the capes are embroidered according to the use of the era, or if the shoe buckles were made of gold or silver and the buttons of precious metals. Everyone wore a wig with loose curls on their heads. There is some controversy regarding the use of wigs, and although in colonial Brazil it would be an attribute of a magistrate, it is reported that some men who aspired to certain nobility also wore them. In any event, the wig as well as all the clothing marked the social distinction.

The hierarchical position that the brothers have within the Brotherhood may be identified in accordance with the place they occupy in the procession. The function of the first group that opens the procession, in particular that which sustains the standard of the Order, may not be the same as the four brothers who bear the three coffins, neither of which is put in set two, between the coffins. After the third coffin, the representatives of the clergy appear with their ecclesiastical garments displaying the tonsure on their bare heads. Among them, one raises the crucifix high, placing it approximately at the same height as the black poles. There is a sacred relationship between the flag that represents the Virgin Mary, Our Lady of Mercy, which opens the procession, and the crucifix lifted at the end representing her crucified son. Mary represents her own mercy, the one that intervenes in favor of the condemned, together with her son Jesus Christ. Within the numerous 
coffins are the bones of sinners awaiting holy burial, while their souls await the remission of sins and the embodiment of the promise of salvation invoked in the sacrifice of Christ. There is nothing to indicate that the procession occurs in an urban scenario, although the urbanism of the 18th century in Bahia could imply the absence of pavement and parts of the city with deserted passages and no buildings. However, the scenario and the composition of the scene of the panels maintain a great similarity, as noted on the panel in front, representing the Procession of the Torches.

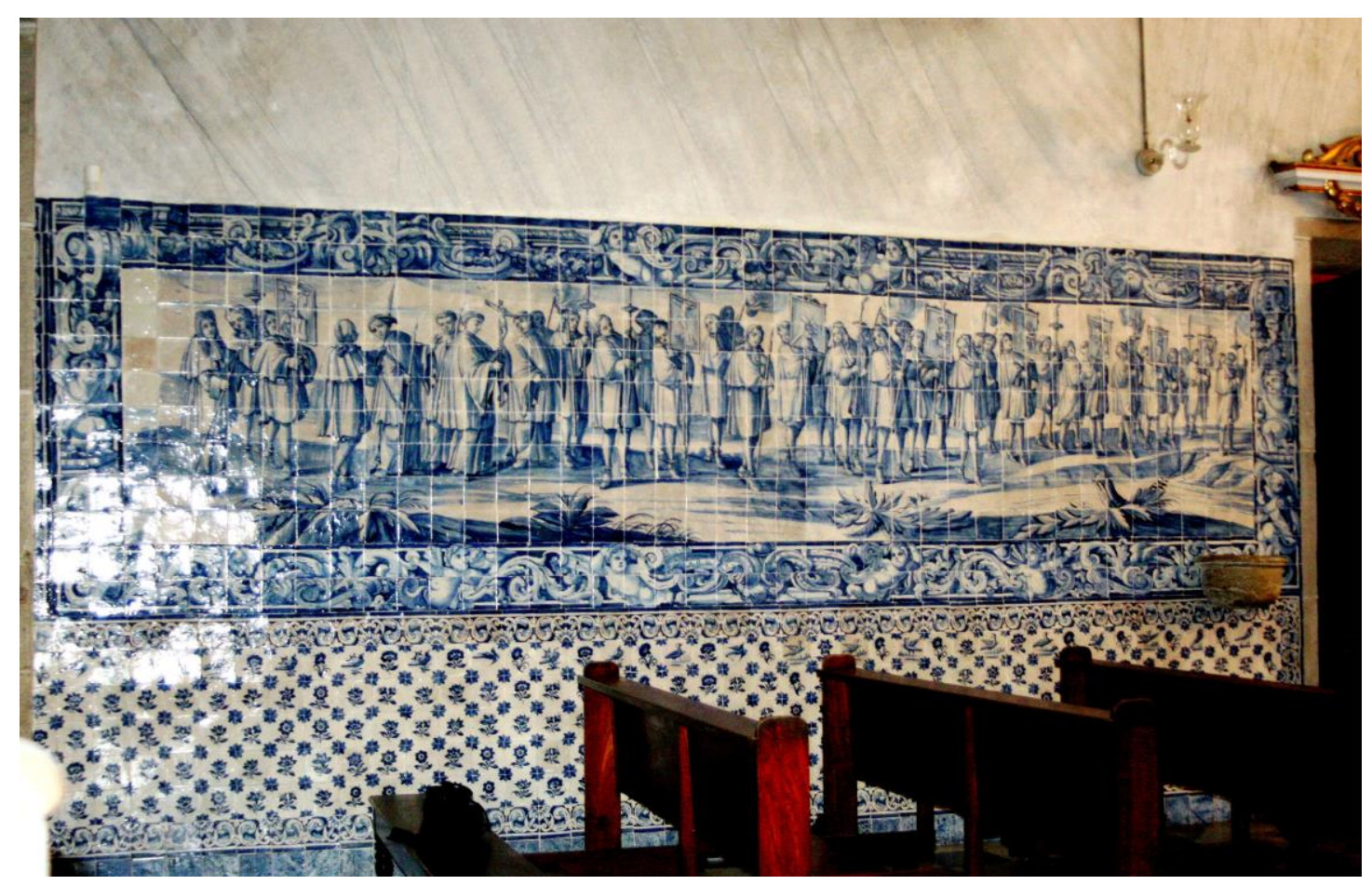

Fig. 3 - The Procession of the Torches, the left-hand panel of the main altar. Source: Courtesy of the Holy House of Mercy, Bahia.

However, it should be considered that Antonio de Abreu, the painter of the tiles, fashioned them in Lisbon and, in addition to not having the slightest idea of what eighteenth-century Salvador was like, did not receive the task to represent the city but only the procession; and this is how it turned out. Thus, the tiles, regardless of who they represent, are framed primarily in the Portuguese style in vogue at the time. Portuguese artists, as well as the other artists in the rest of Europe, resorted to engraving at the time in Portugal, as they were mostly Dutch. The Dutch also influenced the color (blue), the graphical treatment and the provision of the scenes of the panels.

The prestige of the Dutch, as well as being an influence, also led them to seek to overcome the competition by looking for artists trained in the academy who were masters of easel painting. The tiles, such as the tables, are framed. The frame is straight as in the tiles of the Holy House. This phase is characterized by an increase in the production of tiles in Portugal, caused, among other factors, by the Brazilian demand and also the fact that its great painters also became well known. The increase in production affirms the historiography of Portuguese art, and led to iconographic 
repetition in different areas, with the scenes undergoing framing. It is noted that the three panels of Mercy repeat the same iconography, replacing only the larger object of the procession, and in the case of the procession of the bones, the coffins. The repetition of the iconography concentrated on the tile theme, subjected to the model of the eighteenth century may explain the absence of a reference to the urban landscape and also the clothing of the characters; this certainly would have been Portuguese but that in the case of representation the wig was incorporated, whose use in Brazil is not confirmed by historians.

Portugal, from the 16th century, had encrypted the profession of artisans. A task that had fallen to Duarte Nunes de Leão according to the Livro dos Regimentos dos Oficiais Mecânicos de Mui Nobre e sempre Leal Cidade de Lisboa (BAZIN, 1983, p. 41-42). Trades were governed by the House of Twenty-four (where each profession was represented by an elected judge). This institution did not exist in Colonial Brazil. Here, trades were governed by judges and controlled by City Hall. Initially, they were organized into brotherhoods. Subsequently, in accordance with the affinities, they underwent a division regulated by royal charter on December 3, 1771.

The construction of a church demanded masons, stone carvers, plasterers in stone and plaster, carpenters, joiners and cabinetmakers. Sculptors, blacksmiths, locksmiths and even potters, tilers and roofers were also sought. It is worth mentioning that in Colonial Brazil these trades were not separated with the same rigor of medieval guilds. This was probably due to a lack of or poor vocational training, as well as the lack of artisans and it was not unusual that the same individual would perform more than one trade (BAZIN, 1983, p. 42-43). This situation allows us to understand why the material and craftsmen came from the metropolis. Among the material which arrived there were the tiles.

Nevertheless craftsmen, regardless of the function they exercised, were poorly paid. In the case of the new church of Mercy, built in the 18th century, the construction was sponsored by the brothers whose religious fervor did not align with the daily shortages of experienced professionals; these professionals were probably unable to escape a bad salary. After all, the ultimate goal of the Brotherhood was the construction of a building that marked the urban landscape of the city. The use of quality materials assured beauty in the completion of the building, but even so, it was not always enough. Every order or Brotherhood wanted its construction to be the most beautiful in the city. In the case of the churches of the Tertiary Order, and in particular the Brothers of Mercy to the extent that the brothers were not holy and could not be represented at the altar; there was nothing more righteous for them than to display themselves and their works near the most sacred and important place of the church.

The combination of form and content of the panels, materials (fine quality of the plaster) and colors (blue Chinese porcelain), the technique (enhanced by the Dutch presence) and the design, the 
composition of the scene and the characters participating in it do not offer "a pleasing spectacle" due to their aesthetic value, to look at. The composition of the panels allows going beyond simple representation. The panel carries a meaning that goes beyond what is seen. The great importance of the Portuguese tiles may consist in the fact that it was integrated into the architecture, thus creating conditions that allowed scenic metamorphosis thanks to the arrangement of spaces. In convents and churches figurative representations had become increasingly frequent. However, to the extent that the panels were not the same proportion as the engraving, the perspective changed and by repeating the figures, they could be distinguished only from their clothing and insignia. In short, the artist copied the engraving, and just the essentials. Consequently, the design was not seeking nor could it seek, due to the distance separating the artist from the Brothers, the individual representation of each. The status they had within the local society and, consequently, within the Order was indicated by their clothing and the place they occupied in the procession.

If we return to the statutes of the Holy House of Mercy, we realize that belonging to the Tertiary Order carried a certain social prestige. Therefore it seems legitimate that the Brothers, when sponsoring the construction of the new church in the eighteenth century, sought to perpetuate part of their work through the representation of three major processions.

The procession of the bones as well as all the processions of the colony were supported in canon law and by the laws and ordinances of the Kingdom. Although the procession of the bones was due to a decree of the king himself, the church would not give up on claiming for themselves what they thought was their right under Title XIII of the First Constitutions of the Archbishop of Bahia 1707, which defined the procession as "a public prayer to God by a group of devotees" (MENDES, 2011, p. 29). The Archbishop also kept to himself the right to regulate

these acts of true religion and divine worship, with which we recognize God as the Supreme Lord of all and distributor of all goods and therefore subject ourselves to him awaiting the mercy of his Divine graces and favors that we ask of him for the salvation of our souls, remedy for our bodies and our needs (MENDES, 2011, p. $30)$.

Dying in the eighteenth century did not involve only leaving life, and passing to the heirs the task of executing the will and inventory of the property gained upon death. The salvation of the soul was the most important goal to be achieved. Since the seventeenth century the development of preparations for death constituted in a task that should be thought about in advance by seizing death, "better to dominate it by reintegrating it into the perspective of salvation", such was the extent that the Church sought to impress the inevitable. However, instead of denying it, it was placed at the center of life (VOVELLE, 1974, p. 57). In Catholic European countries, thinking about death meant thinking about the will, which should be written in advance, setting forth the 
order for the carrying out of the mass, which was followed by the return of any goods that had been acquired illegally and the payment of debts. The preoccupation with death acquired thus a material dimension, linking the salvation of the soul to the assets achieved in life. In Brazil, the rule of determining the will was not always carried out in youth; it was postponed until old age or if the occasion presented itself due to a serious illness.

The death of another would also contribute to matters of musings on one's own death. Skeletons, bones, especially the skull, and the crucifix are frequent motifs in paintings, offering tangible elements for dialog with the invisible. No wonder that the preparation of manuals for death placed the will at the same level as spiritual exercises. In using this type of document, formulas developed in the seventeenth century can be easily identified. The importance of these formulas was so great that its practice was extended in Brazil until the mid-twentieth century (RODRIGUES; DILLMANN, 2013, p. 2).

It was a Jesuit who introduced testamentary formulas to the Portuguese colony. The first was the work of Father Estevam de Castro and was entitled, Breve aparelho e modo fácil para ensinar a bem morrer o Cristão. First published in Portugal in 1621, it was so successful that it was reprinted eleven times. Other manuals followed in the next century. Wills could be drafted by the interested party or, in the case of the Brothers of Mercy, the wording could be carried out by another member of the Brotherhood. The Philippine Ordinances, Book 4. Titles 80/85 prohibited the family from redrafting or witnessing the writing of the will, though considering the logic of the time, these would be the heirs/beneficiaries of the estate of the testator. Eighteenth-century wills were not written by notaries, which shows that the concern of the testator was focused on the salvation of his soul (RODRIGUES; DILLMANN, 2013, p. 3).

Rodrigues and Dilmann draw attention, with support in Brazilian history, to the effect that the testamentary formula of João Franco had in Brazil from approximately 1759. This was long after the setting of the Mercy panels. What matters here is the iconographic production of the late Middle Ages, the time that João Franco refers to when teaching how to die. It is possible to detect in João Franco, the survival of medieval beliefs in the eighteenth century (RODRIGUES; DILLMANN, 2013, p. 4). These beliefs led to the frequent representation of the souls of the damned as part of the Final Judgment theme. This theme, which was highlighted in the exterior facades of the Romanesque and Gothic cathedrals of the twelfth and thirteenth centuries, was widely reported in the painting and Italian and Flemish engraving of the fourteenth, fifteenth and early sixteenth centuries. The artistic expression of these paintings is the bearer of a pedagogical message that displays the tortures of hell, from which purgatory offers the possibility of escape.

Purgatory, besides being a tertiary place in the cartography of the beyond, introduced the figure of the intercessor, who would advocate in favor of the souls of sinners. Throughout the 
seventeenth century, Saints were called to the exercise of this function in much of Europe. However, in the Iberian Peninsula especially in Spain and the heavenly court, this iconography from the late Middle Ages kept its prestige with Mary, the Pious Virgin or the Virgin of the Seven Sorrows. At the same time, images of the Virgin displaying the breast that nourished Jesus or the Virgin of Mercy harboring the faithful under her mantle decreased significantly. However, this image of the Virgin's almost explicit disappearance as intercessor along with her son does not mean a breach of its presence in the iconography of purgatory. Rather, "the virgin's intervention will now manifest itself by way of an indirect pedagogy, which encourages these practices" (VOVELLE, 2008, p. 171). In the case of Mercy such practices were determined, as it turned out, by the Commitment of the order itself and supported by the legislation of the kingdom. Not that this was the only indirect figuration of Mary; the image of the Virgin kneeling at the feet of the child, displaying the cross was also widely publicized at the time.

From the seventeenth century and especially in the eighteenth century, Catholic Europe made use of the figurative image to spread the belief in purgatory. It is evident that the reference to Catholic Europe consists of a very large area. It is necessary to contemplate belief in purgatory in Portugal and under what conditions it arrived in Brazil. It should be considered that the penetration of the themes of the post-Tridentine ministry, from Milan and Rome, were not reflected in the same way in all European realms. The sovereigns also felt it fitting that salvationist beliefs became more widespread. In Portugal the monarchs were engaged in the task as well. At the time of the era herein discussed King João V (1707-1750), from the beginning of his reign, showed a burning devotion and was greatly invested in releasing souls from purgatory. In the metropolis, as we know, the King's relations with the Mercy were very intense and in this sense the Brothers of Mercy on both sides of the Atlantic kept a very close and sometimes even family-type relationship. Although the belief had been introduced in Brazil by the Jesuits and the Franciscans, the role of Tertiary Brotherhoods during the period was also of great importance.

In the Mercy panel, representing the procession of the bones, there are several actors: the artist who prepared the panels, the church that spread the model of the image in tandem with the orders and the devotees, represented by the brotherhood that commissioned the order. The belief in purgatory is implicit in the panels, and to understand the meaning of the image it was necessary to know the will of the Brothers. Even so, one cannot rediscover the authenticity of a belief in what was the result of a commitment between the different associates. What the panels tell us are merely traces, but significant traces of a belief. The reading of the narrative that the procession of the bones represents only allows us to conclude that it was a public display of the Bothers of the Order of Mercy under the control of the Church, seeking to perpetuate the social prestige of the panels that represent the three processions. However, it also represents those who are alive and contemplate the 
panels. In addition to the indirect presence of the Virgin of Mercy, which motivates the act, and is symbolically represented on the standard that opens the procession, the invisible purgatory in the picture is virtually an allusion to possible access to heaven.

In this sense, the procession of the bones brings back the macabre, so prominent in the Middle Ages, but the procession of coffins hides the bones of the damned within. Note that the macabre in other contemporary representations is present in the skull figuration of crossbones or even in the skeleton portraying his own death, as it appears in medieval macabre dance. The bones, like purgatory, are not portrayed offering a reflection on death. In the seventeenth century churches of Bahia the tradition gained new meanings through a category which is the very paradox of visual arts: the invisible.

\section{References}

BAZIN, Germain. A arquitetura religiosa barroca no Brasil. Rio de Janeiro: Record, 1983. v. 1.

COMPROMISSO da Misericórdia de Lisboa. Biblioteca Nacional do Rio de Janeiro. Lisboa, 1598.

HENRIQUES, Paulo. Lisbonne avant le Tremblement de terre. Le panneau du musée de 1'Azulejo. Paris: Editions Chandeigne, 2005.

MENDES, Ediana Ferreira. Festas e procissões reais na Bahia colonial. Dissertação (Mestrado em História Social) - Universidade Federal da Bahia, Salvador, 2011.

REIS, João José. A morte é uma festa - Ritos fúnebres e revolta popular no Brasil do século XIX. São Paulo: Companhia das Letras, 1991.

RIBEIRO, Maria Eurydice de Barros. Entre o prestígio dos homens e a salvação dos céus: As irmandades de Misericórdia e a Assistência médico-hospitalar da Bahia (séc. XIX). Textos de história, Brasília, n. 1, v. 1, 1993, p. 1-17.

RODRIGUES; DILMANN. Desejando por a minha alma no caminho da salvação. Modelos católicos de testamentos no século XVIII. História Unisinos, n. 17, 1, jan./abr., 2013, p.1-11.

TÍTULO 137: Das execuções das penas corporais. In: Ordenações Filipinas. Livro 5. Disponível em: http://www1.ci.uc.pt/proj/filipinas/15p1314.htm. Consultado em: 19 dez. 2014.

VOVELLE, Michel. As almas do Purgatório ou o trabalho de luto. São Paulo: UNESP, 2010.

VOVELLE, Michel. Mourir autrefois. Paris: Gallimard/Julliard, 1974. 
Maria Eurydice de Barros Ribeiro. PhD Professor - Department of Visual Arts and the Postgraduate Arts Program. Institute of Arts. Department of History. Institute of Human Sciences. UNB - Universidade de Brasília - Darcy Ribeiro Campus, Asa Norte, 70910-900 Brasilia-DF

Received in 01/05/2015

Approved in 02/25/2015 